\title{
Lithiasis of Minor Salivary Gland Mimicking a Venous Malformation: Contextual Diode Laser Photocoagulation and Excision
}

\author{
Giuseppe Barile $^{1}$, Eleonora Quercia ${ }^{1}$, Leonardo Barulli ${ }^{1}$, Eugenio Maiorano ${ }^{2}$ \\ 1. Department of Interdisciplinary Medicine, University of Bari Aldo Moro, Bari, ITA 2. Emergency and Organ \\ Transplantation, University of Bari Aldo Moro, Bari, ITA
}

Corresponding author: Giuseppe Barile, g.barile93@hotmail.it

\section{Abstract}

Sialolithiasis is the most common disease of the major salivary gland. Lithiasis of minor salivary gland, instead, is very rare. Diagnosis is often challenging as frequency, clinical appearance and symptoms are relatively unknown. We report on a case of minor salivary gland lithiasis of the cheek resembling a venous malformation and its management by diode laser.

Categories: Dentistry

Keywords: lithiasis, minor salivary gland, venous malformation, diode laser, photocoagulation, cheek

\section{Introduction}

Minor salivary gland lithiasis (MSGL) is extremely rare, as it represents approximately two percent of all cases of sialolithiasis [1, 2]. Although data reported in the literature on frequency, signs, and symptoms of MSGL are relatively unknown, it is generally described as a firm, solitary, submucosal painless nodule with hard consistency and mobility in the surrounding tissue, mainly occurring in lips and buccal mucosa [1-4]. MSGL is frequently misdiagnosed, especially when associated with masticatory trauma and/or resembling other benign minor salivary gland disease $[1,3,5]$. We describe a case of MSGL of the cheek mimicking a venous malformation, treated by diode laser photocoagulation and contextual laser excision.

Received 03/02/2020 Review began 03/08/2020 Review ended 03/13/2020 Published 03/17/2020

\section{(c) Copyright 2020}

Barile et al. This is an open access article distributed under the terms of the Creative Commons Attribution License CC-BY 4.0., which permits unrestricted use, distribution, and reproduction in any medium, provided the original author and source are credited.

\section{Case Presentation}

A 55-year-old male was sent to our observation for a persistent lesion of the cheek. The intraoral examination revealed a firm, nodular lesion with a soft consistency and blue-violet appearance. Under pressure with transparent glass, a hard structure was clearly visible within the lesion. To prevent intraoperative bleeding, the lesion was firstly photocoagulated by diode laser (wavelength $800 \pm 10$ $\mathrm{nm}$; continuous wave, output energy $5 \mathrm{~W}$ ) and immediately removed by the same laser with different settings (continuous wave, output energy $1 \mathrm{~W}$ ). Bleeding was absent during and after excision and stitches were unnecessary. The histological examination led to the diagnosis of MSGL. The patient was followed-up after seven days and completely recovered after 15 days (Figure 1).
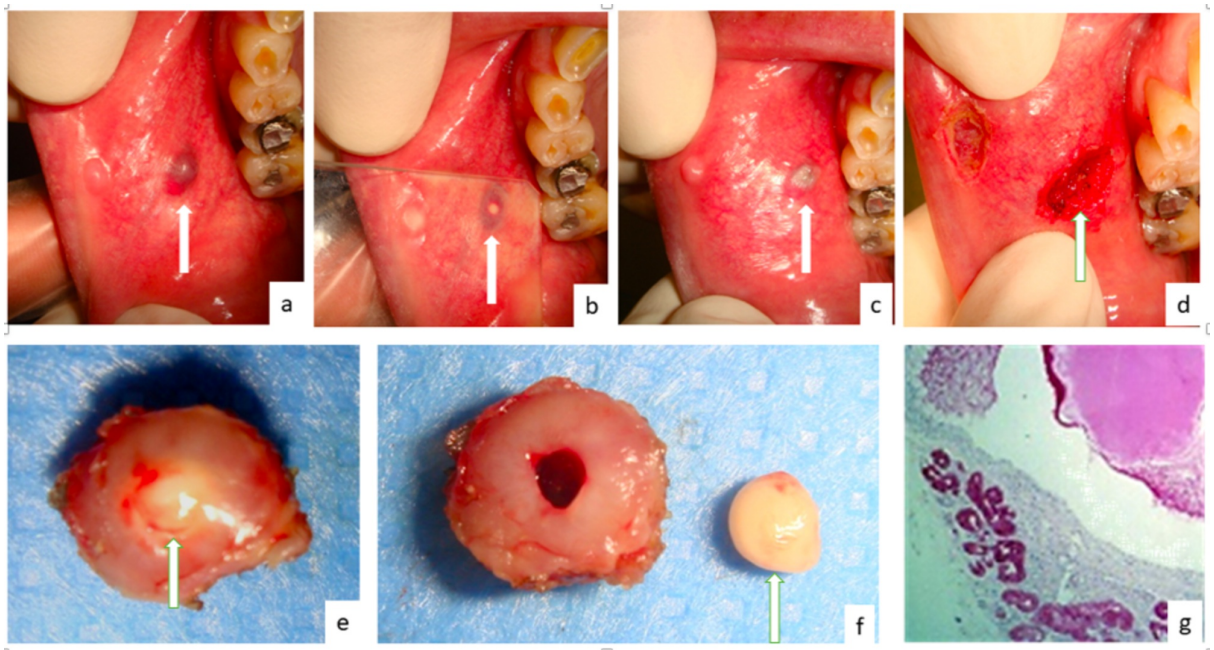

FIGURE 1: Case presentation

a) blue-violet lesions of the cheek (arrow), associated with a small and normally colored lesion appearing as a venous malformation of the cheek; 
b) under the pressure of transparent glass, a yellowish and hard nodule is detectable within the blue-violet lesion (arrow);

c) color variation of white-grey after diode laser treatment (arrow);

d) subsequent laser excision of both lesions;

e) the entire surgical sample;

f) sample with the sialolith removed;

g) histological examination showing a cyst-like lumen containing mucina and obstructed by the sialolith.

\section{Discussion}

MSGL is frequently misdiagnosed because of unspecific clinical signs and symptoms but also because of resemblance with other benign diseases of the minor salivary gland, especially mucocele, or traumatic lesions of the buccal mucosa $[1,2,6,7]$. In the reported case, the clinical appearance of a venous malformation of the buccal mucosa was probably related to chewing trauma, as the small lesion detectable nearby, histologically diagnosed as a traumatic fibroma, confirms that. The management of venous malformation by a diode laser, providing a targeted selectivity for oxyhemoglobin, induction of photothermolysis and erythrocyte micro-agglutination and vessel obliteration, is widely reported in the literature [8-10]. Overall, the advantages of diode laser use in several oral surgery and periodontal procedures (e.g., periodontal decontamination, not surgical treatment of gingival overgrowth, surgical excisions of benign oral mucosal lesions and also surgical resection of oral carcinomas) are antibacterial activity, absence of bleeding during cutting with reduction of postoperative edema, unnecessary stitches, and fast mucosal healing [8, 11-16]. Based on this, in the surgical planning of the current case authors decided preliminary treat the vascular component and subsequently remove the entire lesion.

\section{Conclusions}

Nowadays, among all lasers with surgical capabilities, the diode laser is the most used for the surgical excision of oral mucosa lesions as well as photocoagulation of small and large venous malformations in the head and neck. It is safe, decisive and allows to simplify the procedures for both clinicians and patients.

\section{Additional Information}

\section{Disclosures}

Human subjects: Consent was obtained by all participants in this study. Conflicts of interest: In compliance with the ICMJE uniform disclosure form, all authors declare the following: Payment/services info: All authors have declared that no financial support was received from any organization for the submitted work. Financial relationships: All authors have declared that they have no financial relationships at present or within the previous three years with any organizations that might have an interest in the submitted work. Other relationships: All authors have declared that there are no other relationships or activities that could appear to have influenced the submitted work.

\section{References}

1. Ben Lagha N, Alantar A, Samson J, Chapireau D, Maman L: Lithiasis of minor salivary glands: current data . Oral Surg Oral Med Oral Pathol Oral Radiol Endod. 2005, 100:345-348. 10.1016/j.tripleo.2004.12.023

2. Okada H, Yokokawa M, Komiya M, Akimoto Y, Kaneda T, Yamamoto H: A rare case of sialolithiasis of the lower lip simulating a mucocele and review of the literature. Quintessence Int. 2011, 42:589-594.

3. Lee LT, Wong YK: Pathogenesis and diverse histologic findings of sialolithiasis in minor salivary glands . J Oral Maxillofac Surg. 2010, 68:465-470. 10.1016/j.joms.2009.03.041

4. Wang WC, Chen CY, Hsu HJ, Kuo JH, Lin LM, Chen YK: Sialolithiasis of minor salivary glands: A review of 17 cases. J Dent Sci. 2016, 11:152-155. 10.1016/j.jds.2015.10.006

5. Brazao-Silva MT, Prosdocimi FC, Lemos-Junior CA, de Sousa SO: Clinicopathological aspects of 25 cases of sialolithiasis of minor salivary glands. Gen Dent. 2015, 63:e22-e26.

6. Karengera D, Yousefpour A, Mir Mohammad H, Lechien P, Reychler H: Minor salivary gland lithiasis simulating a mucocele. Apropos of a case. Rev Stomatol Chir Maxillofac. 1997, 98:81-83.

7. Kimura M, Enomoto A, Shibata A, Nishiwaki S, Umemura M: A case of sialolithiasis in a minor salivary gland of the buccal mucosa. J Clin Diagn Res. 2016, 10:6-7. 10.7860/JCDR/2016/21977.8766

8. Limongelli L, Tempesta A, De Caro A, Maiorano E, Angelelli G, Capodiferro S, Favia G: Diode laser photocoagulation of intraoral and perioral venous malformations after tridimensional staging by high definition ultrasonography. Photobiomodul Photomed Laser Surg. 2019, 37:722-728. 10.1089/photob.2019.4635

9. Bacci C, Sacchetto L, Zanette G, Sivolella S: Diode laser to treat small oral vascular malformations: A prospective case series study. Lasers Surg Med. 2018, 50:111-116. 10.1002/1sm.22737

10. Capodiferro S, Limongelli L, Tempesta A, Maiorano E, Favia G: Diode laser treatment of venous lake of the 


\section{Cureus}

lip. Clin Case Rep. 2018, 6:1923-1924. 10.1002/ccr3.1735

11. Angiero F, Parma L, Crippa R, Benedicenti S: Diode laser $(808 \mathrm{~nm})$ applied to oral soft tissue lesions: a retrospective study to assess histopathological diagnosis and evaluate physical damage. Lasers Med Sci. 2012, 27:383-388. 10.1007/s10103-011-0900-7

12. Capodiferro S, Tempesta A, Limongelli L, Maiorano E, Benedicenti S, Favia G: Nonsurgical periodontal treatment by erbium: YAG laser promotes regression of gingival overgrowth in patient taking cyclosporine a: a case report. Photobiomodul Photomed Laser Surg. 2019, 37:53-56. 10.1089/photob.2018.4478

13. Limongelli L, Capodiferro S, Tempesta A, et al.: Early tongue carcinomas (clinical stage I and II): echoguided three-dimensional diode laser mini-invasive surgery with evaluation of histological prognostic parameters. A study of 85 cases with prolonged follow-up. Lasers Med Sci. 2020, 35:751-758. 10.1007/s10103-019-02932-z

14. Capodiferro S, Maiorano E, Loiudice AM, Scarpelli F, Favia G: Oral laser surgical pathology: a preliminary study on the clinical advantages of diode laser and on the histopathological features of specimens evaluated by conventional and confocal laser scanning microscopy. Minerva Stomatol. 2008, 57:1-7.

15. Saydjari Y, Kuypers T, Gutknecht N: Laser application in dentistry: irradiation effects of nd: YAG $1064 \mathrm{~nm}$ and diode $810 \mathrm{~nm}$ and $980 \mathrm{~nm}$ in infected root canals-a literature overview. Biomed Res Int. 2016, 2016:8421656. 10.1155/2016/8421656

16. Ortega-Concepción D, Cano-Durán JA, Peña-Cardelles JF, Paredes-Rodríguez VM, González-Serrano J, López-Quiles J: The application of diode laser in the treatment of oral soft tissues lesions. A literature review. J Clin Exp Dent. 2017, 9:925-928. 10.4317/jced.53795 